\title{
Spedbarn skal sove på rygg - en epidemiologisk suksesshistorie
}

\author{
Nina Øyen \\ Institutt for samfunnsmedisinske fag, Universitetet $i$ Bergen \\ Medisinsk fødselsregister, Nasjonalt folkehelseinstitutt, Bergen \\ Senter for medisinsk genetikk og molekylarmedisin, Haukeland universitetssykehus, Bergen \\ Korrespondanse: Nina Øyen, Afdeling for Epidemiologisk Forskning, Statens Serum Institut, Artillerivej 5, DK-2300 København, Danmark \\ E-post: noy@ssi.dk
}

Foreldre redder mer enn 100 spedbarn hvert år i Norge fordi de lar dem sove på ryggen. Medisinsk fødselsregister har vært sentral i å vise at krybbedød økte allerede på slutten av 1970-tallet, at økningen skyldtes den populære sovestillingen mageleie, at ryggleie hindrer krybbedød, og at vi fortsatt må overvåke hyppigheten av krybbedød og forekomsten av risikofaktorene i spedbarnspopulasjonen. Epidemiologiske studier danner det viktigste bevisgrunnlaget for årsaken til krybbedød.

På midten av 1980-tallet kom det alarmerende rapporter om at en mulig epidemi av krybbedød var under utvikling i Norge, Sverige og Finland. ${ }^{1-3}$ Med basis i Medisinsk fødselsregisters registreringer av alle fødte i årene fra 1967 til 1984, koblet med dødsmeldinger for alle spedbarnsdøde, ble det vist at på slutten av perioden var det en økning i total spedbarnsdødelighet etter første leveuke (postperinatal dødelighet) som med stor sannsynlighet kunne tilskrives en økning i krybbedød. ${ }^{1}$

Krybbedød er definert ved eksklusjon. Det vil si at det skal ikke være andre symptomer og funn, ${ }^{4}$ eller omstendigheter $^{5}$ ved et plutselig og uventet dødsfall i første leveår som kan forklare dødsfallet. Denne måte å innkretse krybbedød på har vært en utfordring for epidemiologer. ${ }^{6}$ For det første trengte en et overvåkningssystem for plutselig død som de fleste land ikke hadde etablert, for det andre var en åstedsbefaring og obduksjon ikke mulig for alle plutselig spedbarnsdødsfall, med fare for seleksjonsbias og grov underestimering av krybbedød, og til sist har det tidligere ikke vært standardiserte prosedyrer eller samstemte oppfatninger av hva som kunne ha forårsaket det plutselige spedbarnsdødsfallet, selv for et obdusert spedbarn.

De fleste krybbedødsfall skjer rundt 3-månedersalderen. Slike dødsfall er mer sjeldent i første levemåned og etter 6 måneder. Den spesielle aldersfordelingen har lenge gitt mistanke om at noen barn har en medfødt modningsfeil eller en fysiologisk sårbarhet på dette alderstrinnet, og at dette gjør dem særlig utsatt for å dø, dersom ytre utløsende faktorer er til stede.

Både i Norge og i andre land ble økningen i krybbedød bortforklart, særlig av patologer, med en økende bruk av diagnosen krybbedød på dødsmeldingen på slutten av 1980-tallet. Det ble derfor tatt initiativ til å gjennomgå alle spedbarnsdødsfall i perioden 1967 til og med 1988 for å finne ut om økningen var reell i Norge. ${ }^{7}$ Det viste seg at ratene av krybbedød var mer enn fordoblet (figur 1). Tidlig i perioden ble krybbedødsfall feilklassifisert under andre diagnoser og kom dermed ikke med i den offisielle statistikken over plutselig uventede dødsfall fra slutten av 1960-årene til begynnelsen av 1980-årene. Med basis i reklassifiserte spedbarnsdødsfall fra 1967 til og med 1988 kunne en vise at antall krybbedøde økte fra 64 (0,98 per 1000 som overlevde første leveuke) av fødte i 1971-årgangen til en topp på 88 (1,6 per 1000) i 1975, deretter fra 66 (1,3 per 1000) i 1977 til så mange som 154 krybbedøde (2,7 per 1000) født i 1988. Økningen av krybbedøde var enda mer dramatisk dersom en også justerte ratene for demografiske endringer i fødepopulasjonen, slik som mors alder og nummer i søskenflokken. Økningen var da mer enn tredoblet.

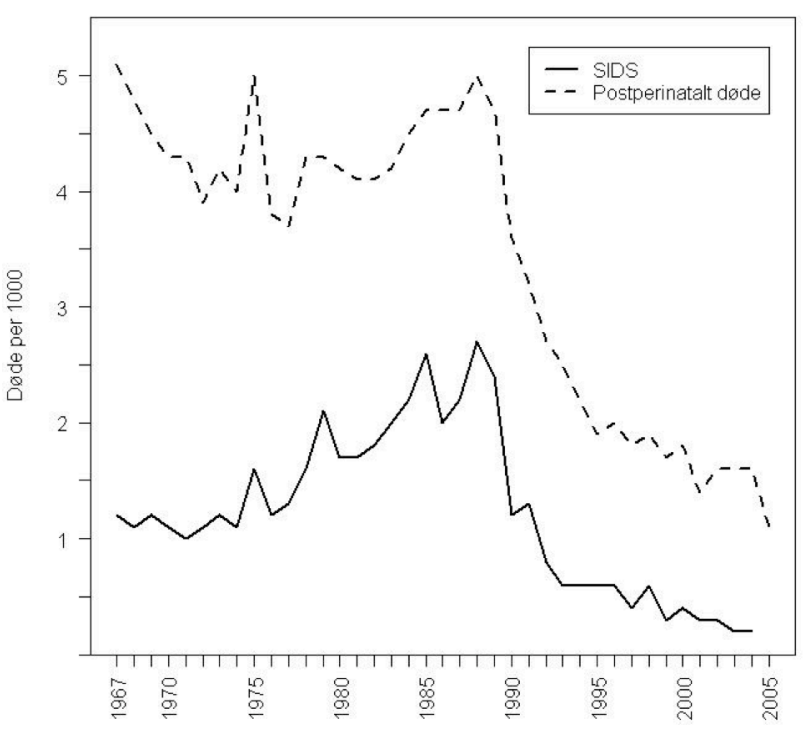

Figur 1. Krybbedødsrater og total postperinatale dødelighetsrater per 1000 i Norge 1967-2005. Ratene er basert på Medisinsk fødselsregisters SIDS database ${ }^{7}$ hvor tallene bygger på en revisjon av dødsmeldinger for alle postperinatale dødsfall. Ratene for periodene 1967-96 og 19972005 er basert på henholdsvis fødselsår og dødsår. Tall for krybbedød i 2005 foreligger ennå ikke. 
Økningen forble et mysterium, og en sensasjonspreget presse spekulerte vilt over årsakene. Hovedkildene til disse spekulasjonene lå i patologers observasjoner av det døde spedbarnet og fysiologiske studier av dyr. I denne fasen ble svært mange skumgummimadrasser kastet, og det ble innkjøpt svært mange alarmmatter for å registrere pustestans.

Parallelt var det flere epidemiologiske studier, også internasjonalt, som begynte å publisere risikofaktorer for krybbedød i løpet av 1980-tallet. ${ }^{8}$ Risikoen for krybbedødsfall er høyere for guttebarn, spedbarn av yngre mødre og mødre med flere barn. Dette ble også vist i Norge med utgangspunkt i Medisinsk fødselsregister. ${ }^{9}$ Risikoen var også høyere blant dårlig stilte både økonomisk, utdanningsmessig og yrkesmessig, og blant svarte og i urbefolkninger. Mer sårbare for krybbedød var veksthemmede og for tidlig fødte spedbarn, barn av røykende mødre, samt barn båret under ugunstige svangerskapsforhold som infeksjoner, lav blodprosent og svangerskapsforgiftning. De fleste krybbedøde spedbarn døde mens de sov, flere døde om vinteren, noen ganger med en øvre luftveisinfeksjon, og en fant også at de krybbedøde hadde hatt et varmere sovemiljø. En begynte også å sammenligne tidstrender i ulike land og befolkninger.

Ulike rater for krybbedød i etniske og kulturelt forskjellige grupper ledet oppmerksomheten mot mulige forskjeller i spedbarnsstell og soveomgivelser. ${ }^{10,11}$ I befolkninger med en høy forekomst av mageleie var krybbedødshyppigheten høy og vice versa. For eksempel, i Hong Kong ville kinesiske mødre aldri legge spedbarna til å sove på magen, fordi den tradisjonelle sovestillingen var på ryggen. Krybbedød var nærmest ukjent i denne gruppen. ${ }^{10}$ Kunnskapen om dette bidro til mistanken om at mageleie var farlig. Dersom en går tilbake i litteraturen, fremkom faktisk denne mistanken om at mageleie kunne har betydning for krybbedødsrisiko allerede i $1965^{12}$ og ble senere bekreftet i $1970 .^{13}$ Krybbedøde barn ble beskrevet påfallende ofte å ha vært funnet på magen uten at det ble tatt særlig notis av dette før 15-20 år senere. I 1988 gjennomgikk en australsk barnelege flere studier av krybbedød, ${ }^{11}$ også hun bemerket at de krybbedøde oftere ble funnet døde på magen. Denne kunnskapen ble formidlet ukoordinert gjennom media og førte til spontane kampanjer i Nederland og Australia i 1987-88 hvor budskapet var at spedbarn ikke skulle sove på magen fordi dette økte faren for krybbedød. Ganske umiddelbart etter kampanjene ble iverksatt, kunne man se et fall i antall krybbedøde. ${ }^{14,15}$

Imidlertid var det på slutten av 1980-tallet liten enighet om årsakene til krybbedød. Epidemien var alarmerende, særlig i Norge, og initierte en rekke forskningsprosjekter internasjonalt. Ved en nordisk konferanse om krybbedød i Trondheim i februar 1990, besluttet nordiske leger og forskere involvert $\mathrm{i}$ krybbedød å initiere en nordisk populasjonsbasert krybbedødstudie basert på de tre fagområdene epidemiologi, patologi og fysiologi. Her gikk blant annet Nordisk
Ministerråd inn som bidragsyter til forskningsnettverket. ${ }^{16}$ Medisinsk fødselsregister i Bergen var et naturlig utgangspunkt for å koordinere den epidemiologiske kasus-kontroll-studien, men fødselsregisteret var også involvert $\mathrm{i}$ andre større nasjonale forskningsprosjekter $^{17,6,18}$ og senere $i$ den europeiske multisenterstudien av krybbedød. ${ }^{19}$

I 1989 ble sammenhengen mellom mageleie og krybbedød fra kasus-kontrollstudier i henholdsvis Holland $^{20}$ og England ${ }^{21}$ formidlet på internasjonale møter. Da Barneklinikken i Bergen samme år fant at flesteparten av de 42 plutselig døde spedbarn som ble innbragt til Barneklinikken fra 1987 til og med 1989 hadde ligget i mageleie og funnet døde på magen, mens et utvalg av levende spedbarn i større grad sov på ryggen eller på siden, ${ }^{22}$ gikk barnelege Trond Markestad ut i media januar 1990 og advarte foreldre mot å la spedbarn sove på magen. ${ }^{23}$

Parallelt startet en større spørreundersøkelse om spedbarns vanlige sovestilling hvor foreldre til 35000 levendefødte spedbarn født i perioden 1970-1991 ble invitert til å delta. ${ }^{17}$ Foreldre som inngikk i undersøkelsen var trukket ut tilfeldig gjennom Medisinsk fødselsregister, slik at en kunne få den populasjonsbaserte prevalens av spedbarns sovestilling i Norge gjennom en periode på mer enn 20 år (se senere).

I mellomtiden ble virkningen av advarselen mot mageleie gjennom media januar 1990 målt fortløpende ved Medisinsk fødselsregister, og fallet i krybbedød blant fødte i fødselsårgangene 1989 (inkluderer også døde i 1990) og 1990 (også døde i 1991) uteble ikke, verken i Hordaland eller nasjonalt (figur 1). I løpet av ett år gikk raten ned fra 2,7 per 1000 for fødte i 1988 til 1,1 per 1000 i 1990 , en reduksjon på $59 \%$.

Internasjonalt fortsatte imidlertid diskusjonen om hvorvidt sovestillingen virkelig hadde betydning ${ }^{24,25}$ fordi kunnskapen om sammenhengen mellom mageleie og den økte risikoen for krybbedød var innhentet fra kasus-kontrollstudier hvor opplysningene om sovestilling baserte seg på foreldrenes beretninger. Kritikerne viste til at foreldre til døde barn husker bedre enn foreldre til levende barn (differential recall). Den økte risikoen ble også bortforklart av bakenforliggende faktorer som det ikke var tatt høyde for (confounding). Denne diskusjonen førte til at offentlige myndigheter $i$ mange land, deriblant Norge, var nølende til å iverksette offentlige kampanjer for å få foreldre til å unngå mageleie som sovestilling. I USA var også barneleger uvillige til å innrømme at de hadde tatt feil da de tidligere hadde anbefalt mageleie som sovestilling for nyfødte.

Den sterkeste kritikken mot kasus-kontrollstudiene var hele tiden de mulige problemene med foreldrenes erindring om barnets sovestilling og manglende justering for bakgrunnsfaktorer. Derfor ble det i Australia tatt initiativ til en kohortstudie hvor vanlig sovestilling $i$ en definert nyfødtkohort ble kartlagt ved gjentatt kontakt med foreldrene i løpet av første leveår. Kjennskapen til sovestillingen ble altså innsamlet før man 
visste hvilke barn som døde. Denne første og hittil eneste oppfølgingsstudien av spedbarns vanlige sovestilling sammenholdt med senere krybbedødsrater, ble publisert i $1991 .^{26}$ Dødelighetsratene var 4,5 ganger økt for spedbarn som vanligvis sov på magen $\mathrm{i}$ forhold til spedbarn som vanligvis sov på ryggen.

Innenfor helsefaglig forskning kunne et neste steg for å bevise at mageleie faktisk var farlig, ha vært å gjennomføre en randomisert klinisk studie. Det vil si at halvparten av tilfeldig utvalgte fødte spedbarn i en undersøkelse skulle legges på ryggen, mens den andre halvparten skulle legges på magen. Slike studier ble faktisk seriøst diskutert, men heldigvis avvist. Etter hvert ble bevisene så klare, med en sterk statistisk sammenheng mellom mageleie og økt risiko for krybbedød samt konsistente funn i ulike land og befolkningsgrupper. Sammenhengen var også uavhengig av andre bakgrunnsfaktorer.

Nå snudde de offentlige helsemyndigheters tidligere avventende holdning til forskernes resultater. Offentlige kampanjer for å unngå mageleie ble igangsatt i 1991 i Danmark og i 1992 i Norge og Sverige. Innen sommeren 1992 hadde helsemyndighetene i Holland, England, New Zealand og Tyskland initiert offentlige advarsler mot å bruke mageleie som sovestilling, mens USA først kom i gang i 1994 etter anbefaling fra American Academy of Pediatrics.

Foreldre responderte straks. Sovestilling var et så enkelt forebyggende tiltak. I Norge ble krybbedødsraten halvert innen et år, parallelt med fall i forekomsten av mageleie som sovestilling for spedbarn. ${ }^{17}$ Som nevnt tidligere ble antall krybbedøde redusert fra 154 blant fødte i 1988 til 74 i 1990. Parallelle tall for vanlig sovestilling for spedbarn over en 20 års periode kunne nå sammenlignes med fallet i krybbedød. Andelen som vanligvis sov på magen økte fra 7, 18, 37, 50 og 49\% for fødte i henholdsvis 1970, 1975, 1980, 1985 og 1989, for deretter å falle til 27\% for 1990 og $28 \%$ for 1991-årgangene.

Den samtidige endringen i forekomsten av mageleie og hyppigheten av krybbedød i Norge samt også i Sverige og Danmark, i tillegg til tilsvarende utvikling i Holland, England og New Zealand, var med og underbygget den sannsynlige årsakssammenheng mellom mageleie og sovestilling fremkommet i kasus-kontrollstudier og kohortstudier. Konsistente resultater fra epidemiologiske studier av ulikt design og 50\% nedgang i krybbedødsfall etter nasjonale og internasjonale kampanjer sa sitt.

Det ble også svært viktig å få dokumentert hvilken betydning mageleie hadde for nordiske spedbarn i forhold til andre faktorer som kunne være risikofaktorer for krybbedød. Nedgangen i krybbedødsraten var relativt større i vinterhalvåret, hvor det var kjent fra før at krybbedødsraten var høyest, også i Norge. ${ }^{27}$ Dette hadde tidligere ført til at en begynte å lete etter modifiserende faktorer som typisk var til stede $\mathrm{i}$ vinterhalvåret, og som sammen med mageleie kunne øke risikoen ytterligere.
Ved utgangen av 1995 kunne Medisinsk fødselsregister begynne analysene av de nordiske epidemiologiske krybbedødsdataene. Risikoen for krybbedød var 13 ganger høyere for spedbarn som ble lagt til å sove på magen siste gang før det døde, sammenlignet med spedbarn som ble lagt på ryggen siste gang. ${ }^{28}$ Det ble også vist at sideleie økte risikoen 3,5 ganger sammenlignet med ryggleie. At sideleie også var farlig, var fordi barnet lett kunne rulle rundt på magen. Mageleie var spesielt farlig for de tidlig fødte og nyfødte som ble født veksthemmet. Kombinasjonen av mageleie og overoppheting, slik som lett feber, oppvarmet soverom, for mye klær på, eller bruk av lue, var med å øke krybbedødsrisikoen ytterligere. ${ }^{29}$ Videre ble røyking i svangerskapet bekreftet som en risikofaktorer for krybbedød i den nordiske studien, ${ }^{30}$ samt også røykende mødres samsoving med spedbarnet. ${ }^{16,19}$

Den sterke skepsisen mot å se sovestilling i mageleie som en årsakssammenheng lå $\mathrm{i}$ at den ikke kunne forklares ved hjelp av kjente fysiologiske mekanismer. ${ }^{31}$ Det ble også diskutert farlige konsekvenser av å legge spedbarn på ryggen og enda til på siden, ${ }^{32}$ som har vært den tradisjonelle nordiske sovestillingen. Dette bidro dessverre til forsinkelser $\mathrm{i}$ advarsler om sovestillingens betydning, men heldigvis ikke i Norge. I internasjonal sammenheng dreide det seg om titusener av barn som kunne ha unngått krybbedød.

Fortsatt er mange forskere nysgjerrige på hva som kan ligge bak sovestillingens betydning som årsak til krybbedød. I dag, etter at en har kartlagt de menneskelige gener i DNA, har en begynt å søke etter forandringer $\mathrm{i}$ gener som har betydning for reguleringen av hjerterytmen. Slike studier er blitt igangsatt etter at søskenstudier basert på Medisinsk fødselsregisters mødrefiler har vist 5-6 ganger økt risiko for søsken av krybbedøde. ${ }^{33}$ En gjentagelsesrisiko i denne størrelsesorden kan ikke forklares med tilstedeværelse av de samme miljømessige faktorene hos to søsken som begge døde i krybbedød. En medfødt sårbarhet hos begge barn, for eksempel en arvelig faktor, kan være relevant. En rekke genetiske undersøkelser av de døde spedbarna er blitt iverksatt uten at en foreløpig har kunnet forklare det store flertall av krybbedøde.

Imidlertid vil ikke funn fra genetiske undersøkelser kunne rokke ved det viktigste populasjonsrettete tiltaket for å hindre plutselig uventet spedbarnsdød, nemlig at spedbarn skal sove på ryggen. Og et viktig tiltak for at dette faktisk blir gjennomført, er gjentatte offentlige kampanjer, oppdatering av helsepersonellets og nybakte foreldres viten, samt fortsatt overvåkning fra Medisinsk fødselsregister med tanke på endringer av krybbedødshyppighet og forekomsten av risikofaktorer i spedbarnspopulasjonen. ${ }^{34}$

Dessverre ringte ikke alarmklokkene før på slutten av 1980-tallet, selv om en har hatt kjennskap til studier som rapporterte økt risiko for krybbedød i mageleie allerede i 1965. Interessen for spedbarns sovestilling og den økte risiko for plutselig død fikk ikke oppmerksomhet før hyppigheten av krybbedød kunne påvises 
gjennom gode overvåkningssystemer, deriblant slike som Medisinsk fødselsregister hadde fått etablert for krybbedød. I perioden 1965-2004 er det internasjonalt blitt publisert 40 epidemiologiske studier om sammenhengen mellom sovestilling og krybbedød og en metaanalyse av disse studiene har vist en fem ganger økt risiko for krybbedød dersom spedbarna sov på magen $\mathrm{i}$ forhold til de som sov på ryggen (justert odds ratio 4,9; $95 \%$ CI 3,6-6,6). ${ }^{35}$

I ettertid, kan en undre seg over tre forhold, at helsepersonell anbefalte foreldre å legge sine nyfødte til å sove på mage uten noen form for vitenskaplig dokumentasjon, nærmest som et gigantisk motefenomen, at det tok så lang tid å fatte at en epidemi av krybbedød var under utvikling, nesten to tiår, og at den epidemio- logiske kunnskap om sammenhengen mellom mageleie og risiko for krybbedød ble dradd i tvil fordi man ikke forsto hvorfor det var farlig å sove på magen, slik at helsemyndighetenes kampanjer vedrørende spedbarns sovestilling ble ytterligere forsinket.

$\mathrm{Vi}$ vet fortsatt ikke hvorfor mageleie er farlig for noen nyfødte. Det pågår intens forskning for å kartlegge de underliggende forklaringene på at noen spedbarn er sårbare og andre ikke, samt sovestillingens betydning for de sårbare. Imidlertid vet vi at foreldres innsats med å legge spedbarn til å sove på ryggen, er det viktigste enkelttiltak som har bidratt til at mer enn 100 spedbarn ikke dør i krybbedød hvert år i Norge.

Takk til Ørjar Øyen for språkvask og Gry N. Poulsen for figurtegning.

\section{REFERANSER}

1. Irgens LM, Skjærven R, Lie RT. Secular trends of sudden infant death syndrome and other causes of post perinatal mortality in Norwegian birth cohorts 1967-1984. Acta Pcediatr Scand 1989; 78: 228-232.

2. Norvenius SG. Sudden infant death syndrome in Sweden in 1973-1977 and 1979. Acta Pcediatr Scand 1987; Suppl 333: 1-138.

3. Rintahaka PJ, Hirvonen J. The epidemiology of sudden infant death syndrome in Finland in 1969-1980. Forensic Sci Int 1986; 30: 219-233.

4. Beckwith JB. Discussion of terminology and definition of sudden infant death syndrome. I: Bergman AB, Beckwith JB, Ray CG, red. Proceedings of the Second International Conference on Causes of Sudden Death in Infants. Seattle: University of Washington Press, 1970: 14-22.

5. Willinger M, James LS, Catz C. Defining the sudden infant death syndrome (SIDS): deliberations of an expert panel convened by the National Institute of Child Health and Human Development. Pediatr Pathol 1991; 11: 677-684.

6. Øyen N. Sudden infant death syndrome. Epidemiological studies in Norway, Sweden, and Denmark, 19671995 (Thesis). Norsk Epidemiologi 1997; 7 (Suppl 4): 1-73.

7. Øyen N, Irgens LM, Skjærven R, Morild I, Markestad T, Rognum TO. Secular trends of sudden infant death syndrome in Norway 1967-1988: application of a method of case identification to Norwegian registry data. Paediatr Perinat Epidemiol 1994; 8: 263-281.

8. Little RE, Peterson DR. Sudden infant death syndrome epidemiology: a review and update. Epidemiol Rev 1990; 12: 241-246.

9. Irgens LM, Skjærven R. Sudden infant death syndrome and post perinatal mortality in Norwegian birth cohorts 1967-1980. Acta Pcediatr Scand 1986; 75: 523-529.

10. Davies DP. Cot death in Hong Kong: a rare problem? Lancet 1985; 2: 1346-1349.

11. Beal S. Sleeping position and SIDS. Lancet 1988; 2: 512.

12. Carpenter RG, Shaddick CW. Role of infection, suffocation, and bottle-feeding in cot death; an analysis of some factors in the histories of 110 cases and their controls. Br J Prev Soc Med 1965; 19: 1-7.

13. Froggatt P. Epidemiologic aspects of the Northern Ireland Study. I: Bergman AB, Beckwith JB, Ray CG, red. Proceedings of the Second International Conference on SIDS. Seattle: University of Washington Press, 1970: $32-46$.

14. de Jonge GA, Engelberts AC. Cot deaths and sleeping position. Lancet 1989; 2: 1149-1150.

15. Beal S. Sleeping position and sudden infant death syndrome. Med J Aust 1988; 149: 562.

16. Helweg-Larsen K, Øyen N, Milerad J. Pludselig spcedbarnsdød i Norden. Sudden infant death in the Nordic countries. København: Nordisk Minsterråd/Nordic Councils of Ministers, 1997.

17. Irgens LM, Markestad T, Baste V, Schreuder P, Skjærven R, Øyen N. Sleeping position and sudden infant death syndrome in Norway 1967-91. Arch Dis Child 1995; 72: 478-482.

18. Daltveit AK. Geographical, temporal and sociodemographic variations in pregnancy outcome. Epidemiological studies based on the Medical Birth Registry of Norway, The Swedish Medical Birth Registry, and the Nordic SIDS Study (Thesis). Bergen: University of Bergen, 1999.

19. Carpenter RG, Irgens LM, Blair PS, England PD, Fleming PJ, Huber J, Jorch G, Schreuder P. Sudden unexplained infant death in 20 regions in Europe: case control study. Lancet 2004; 363: 185-191. 
20. Engelberts AC, de Jonge GA. Choice of sleeping position for infants: possible association with cot death. Arch Dis Child 1990; 65: 462-467.

21. Fleming PJ, Gilbert R, Azaz Y, Berry PJ, Rudd PT, Stewart A, Hall E. Interaction between bedding and sleeping position in the sudden infant death syndrome: a population based case-control study. BMJ 1990; 301: 85-89.

22. Markestad T, Irgens LM. [Prone position and crib death]. Tidsskr Nor Laegeforen 1995; 115: 3480-3481.

23. Markestad T. Information about sudden infant death syndrom for the general public. Acta Paediatr $1993 ; \mathbf{8 2}$ (Suppl 389): 124-125.

24. Gunteroth WG, Spiers PS. Bedding and sleeping position in SIDS. BMJ 1990; 301: 494.

25. Southall D, Stebbens V, Samuel M. Bedding and sleep position in the sudden infant death syndrome. $B M J$ 1990; 301: 492.

26. Dwyer T, Ponsonby AL, Newman NM, Gibbons LE. Prospective cohort study of prone sleeping position and sudden infant death syndrome. Lancet 1991; 337: 1244-1247.

27. Baste V, Øyen N, Irgens LM, Skjærven R. Seasonality of SIDS in Norway (abstract). International Congress on Sudden Infant Death Syndrome: The Role of Environmental Factors in Infant Mortality, Graz, Austria, 2427 May 1995. Eur J Pediatr 1995; 154: S3.

28. Øyen N, Markestad T, Skjærven R, Irgens LM, Helweg-Larsen K, Alm B, Norvenius G, Wennergren G. Combined effects of sleeping position and prenatal risk factors in sudden infant death syndrome: the Nordic Epidemiological SIDS Study. Pediatrics 1997; 100: 613-621.

29. Helweg-Larsen K, Lundemose JB, Øyen N, Skjærven R, Alm B, Wennergren G, Markestad T, Irgens LM. Interactions of infectious symptoms and modifiable risk factors in sudden infant death syndrome. The Nordic Epidemiological SIDS study. Acta Paediatr 1999; 88: 521-527.

30. Alm B, Milerad J, Wennergren G, Skjærven R, Øyen N, Norvenius SG, Daltveit AK, Helweg-Larsen K, Markestad T, Irgens LM. A case-control study of smoking and sudden infant death syndrome in the Scandinavian countries, 1992 to 1995. The Nordic Epidemiological SIDS Study. Arch Dis Child 1998; 78: 329-334.

31. Poets CF, Southall DP. Prone sleeping position and sudden infant death. N Engl J Med 1993; 329: 425-426.

32. Hunt CE, Shannon DC. Sudden infant death syndrome and sleeping position. Pediatrics 1992; 90: 115-118.

33. Øyen N, Skjærven R, Irgens LM. Population-based recurrence risk of sudden infant death syndrome compared with other infant and fetal deaths. Am J Epidemiol 1996; 144: 300-305.

34. Hill SA, Hjelmeland B, Johannessen NM, Irgens LM, Skjærven R. Changes in parental risk behaviour after an information campaign against sudden infant death syndrome (SIDS) in Norway. Acta Paediatr 2004; 93: 250254.

35. Gilbert R, Salanti G, Harden M, See S. Infant sleeping position and the sudden infant death syndrome: systematic review of observational studies and historical review of recommendations from 1940 to 2002 . Int J Epidemiol 2005; 34: 874-887. 